\title{
-Original一
}

\section{An Utstein-style Examination of Out-of-hospital Cardiac Arrest Patients in Saga Prefecture, Japan}

\author{
Takashi Iwamura, Yuichiro Sakamoto, Noriyoshi Kutsukata, Atsushi Nakashima, \\ Tomoko Yamashita, Youichi Nishimura, Hiroyuki Koami, Hisashi Imahase, \\ Mayuko Yahata and Akiko Goto \\ Emergency Care Center, Faculty of Medicine, Saga University
}

\begin{abstract}
Introduction: The Utstein-style guidelines have been used in various countries around the world, because they are suitable for evaluating regional emergency medical systems (EMSs) for patients who have an out-of-hospital cardiac arrest (OHCA). This report examined the present status of treating OHCA in Saga Prefecture and examined policies that can contribute to improving the rate of the return of spontaneous circulation (ROSC).

Methods: This study examined 800 cases of OHCA by means of the Utstein-style guidelines submitted for medical control verification by firefighting organizations in Saga Prefecture from July 1, 2010, to June 30, 2011. The firefighting organizations were divided into 5 areas (A-E) according to each medical classification. The 5 areas were compared in terms of the ROSC rate and background factors (patient age and sex, cardiac arrest cause, place, witnesses, initial electrocardiogram [ECG], hospital ECG, prehospital medical treatment, transfer time, oral instruction, and bystander cardiopulmonary resuscitation [CPR]).

Results: The ROSC rate was significantly lower in areas D (24.2\%) and E (26.8\%). Age, sex, cardiac arrest cause, place, witnesses, initial ECG, hospital ECG, shock, and adrenaline administration did not differ significantly among the 5 areas. The response time was significantly shorter in areas A (8: 25), D (8: 07), and E (8: 12). There were significantly fewer examples of oral CPR instruction in area $\mathrm{E}(42.1 \%)$, and there were fewer examples of CPR in areas A (44.0\%), D (41.9\%), and E (37.9\%). CPR was performed by lay person in approximately $70 \%$ of the cases in which oral instructions were provided, but it was not performed in $90 \%$ of cases in which no oral instructions were provided.

Conclusions: The Utstein-style guidelines were used to clarify differences in the ROSC rate in Saga Prefecture, thus making improvements in regional EMSs possible. Improvements in the quality of oral instruction and a reexamination of the oral instruction manual are expected to improve the ROSC rate, in parallel with education in basic life support for lay person and in advanced cardiac life support for medical personnel. In addition, it is important to reaffirm the effectiveness of $\mathrm{CPR}$ and encourage the participation of lay person by providing instructions by telephone from an ambulance that is en route to the scene.

(J Nippon Med Sch 2013; 80: 184-191)
\end{abstract}

Key words: cardiopulmonary resuscitation by lay person, oral instruction, regional emergency medical system, telephone cardiopulmonary resuscitation

Correspondence to Takashi Iwamura, Emergency Care Center, Faculty of Medicine, Saga University, 5-1-1 Nabeshima, Saga, Saga 849-8501, Japan

E-mail: iwamura@cc.saga-u.ac.jp

Journal Website (http://www.nms.ac.jp/jnms/) 


\section{Introduction}

A major objective of the Utstein-style, which has been used in countries around the world since in 1991, is to evaluate regional out-of-hospital cardiac arrest (OHCA) and to improve the quality of emergency medical systems (EMSs) ${ }^{1}$. The Fire and Disaster Management Agency of Japan started to collect nationwide data according to the Utsteinstyle guidelines in January 2005. Some valuable reports have been collected as country-wide data according to the Utstein-style guidelines ${ }^{2-7}$. However, the contribution to the regional EMS, which is an original purpose of the Utstein-style guidelines, is left to the medical authorities in each region. This report examined the present status of OHCA in Saga Prefecture, which should be improved at the local level, and explored policies that can help increase the rate of return of spontaneous circulation (ROSC).

\section{Materials and Methods}

\section{Saga Prefecture and EMS in Saga}

Saga Prefecture is a small prefecture with an area of $2,439.65 \mathrm{~km}^{2}$ and a population of 849,709 located in northwestern Kyushu in the western part of Japan ${ }^{8}$. Saga University Hospital, which has an emergency care center, is the only university hospital in Saga Prefecture, is located in the eastern part of the southern area, and is in charge of both the on-line and off-line medical control of Saga Prefecture. The emergency conveyance record that was submitted to the hospital has been verified for all cases from July 2010. However, the emergency conveyance record includes only patients who require hospitalization and does not include less severely ill patients who return home after being transported to the hospital.

There are 7 firefighting organizations (Saga, Kanzaki, Karatsu/East Matsuura, Kito, Tosu/Miyaki, Imari, and Arita) in Saga Prefecture, and prehospital emergency medical systems are provided by each municipal government. As of April 1, 2010, the numbers of emergency life-saving technicians
(ELSTs) and of personnel in each firefighting organization in Saga Prefecture, were 25.9 and 123.8 per 100,000 people, respectively (personal communication, K Yoshida, November 2011).

Medical practice by ELSTs is limited by law? However, some medical practices by ELSTs for treating cardiopulmonary arrest are authorized. An ELST must receive specific instructions for the online medical control by physicians. Procedures that can be performed by ELSTs include establishing an intravenous line and esophageal obturator airway, inserting an endotracheal tube (since 2004) and administering adrenaline (since 2006, if they have received additional training) ${ }^{3}$. Defibrillation with an automated external defibrillator can be performed by ELSTs without online instructions. Patients who have died are not transported to medical institutions but are instead handed over to the police at the discretion of the ELST. However, if the ELST cannot make a decision or if the family of the patient does not accept that transportation is not indicated, then the patient may be transported to a medical institution at the ELST's discretion.

Resuscitation education for the general public is provided mainly by firefighting agencies. Courses for basic life support (BLS) and for advanced cardiovascular life support (ACLS) for healthcare workers are held at random in each district under the guidance of emergency physicians. There is no difference in the resuscitation treatment at each local area in Japan (Guideline 2005 BLS). Changes in the resuscitation guidelines are made in unison according to the guidelines established by the Japanese government.

\section{Patient Inclusion and Data Collection}

This retrospective study examined 814 patients with OHCA for whom an emergency conveyance record (Utstein-style guidelines) was submitted for medical control verification by firefighting organizations in Saga Prefecture from July 1, 2010, to June 30,2011 . Ten patients could be checked for a pulse when the ELST arrived, and 4 patients were transported to a medical institution without 


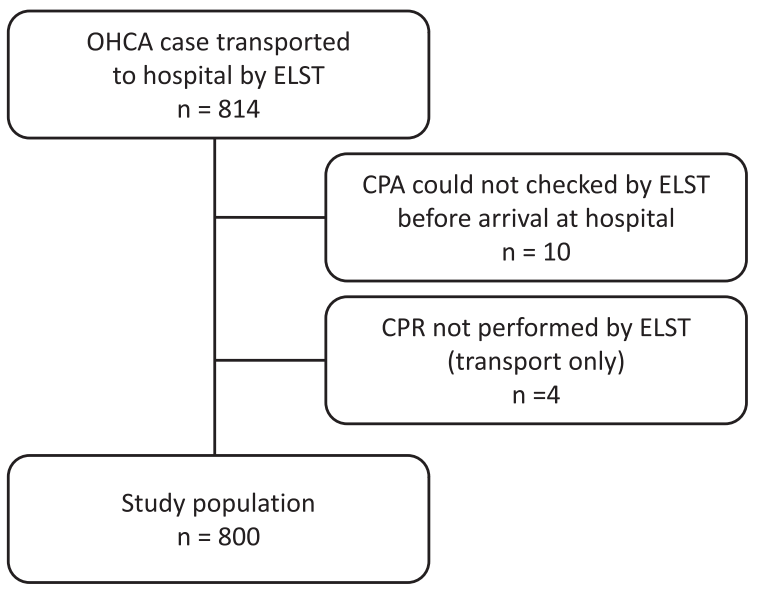

Fig. 1 Flow of study selection

cardiopulmonary resuscitation (CPR) being attempted to be examined by physicians. These 14 patients were excluded. Finally, the remaining 800 patients were analyzed (Fig. 1). However, a patient was included in analysis if defibrillation with an automated external defibrillator was performed before the ELST arrived and if ventricular fibrillation/ventricular tachycardia was confirmed by subsequent analysis.

The 7 firefighting organizations were classified into 5 areas (A-E) according to each medical classification. The 5 areas were compared in terms of the ROSC rate and background factors (age, sex, cardiac arrest cause, place of arrest [home, public facilities, outside, health care facilities for the elderly/clinic, ambulance], initial electrocardiography [ECG], hospital ECG, witnesses, bystander CPR, oral instruction, prehospital medical treatment [treatment of shock, advanced airway management, and adrenaline administration], response time, and time from the scene departure to hospital arrival).

In the original report by Utstein, physicians, nurses, and paramedics were not considered to be emergency personnel unless they act in public as members of an organized emergency response team ${ }^{1}$. However, a purpose of this study was to examine, how many patients underwent CPR performed by lay person who received oral instructions from a dispatcher, and how many cases of bystander CPR by lay person were identified. Therefore, CPR attempts based on oral instructions were limited to those performed by members of the general public, and patients receiving CPR from medical professionals (physician, nurse, rescue workers, and ELSTs) were excluded. Bystander CPR was intended to refer to life-saving treatment that included chest compression, regardless of the presence of a witness. Not described cases about oral instruction were included with oral instruction cases if bystander CPR had already started when a dispatcher received an emergency call. The ROSC rate of hospital ECG asystole was used to indirectly evaluate the quality of the ACLS in each region.

This study was approved by the Institutional Review Board of Saga University.

\section{Statistical Analysis}

The statistical analysis of the ratio scale was done by an analysis of variance, and an analysis of the nominal scale was performed with the Chi-square test and Fisher's test. Two-sided $p$ values less than 0.05 were considered to indicate statistical significance. All statistical analyses were with the IBM SPSS Statistics statistical software package (version 19.0, IBM Corp., Armonk, NY, USA). The figures were constructed with the Microsoft ${ }^{\circledR}$ Office PowerPoint 2007 and Microsoft ${ }^{\circledR}$ Office Excel 2007 software programs (Microsoft Corporation, Redmond, WA, USA).

\section{Results}

The ROSC rate was significantly lower in area D (24.2\%; 30 of 124 cases) than in area A (40.5\%, 135 of 333 cases; $\mathrm{p}=0.001)$ or area $\mathrm{C}(40.0 \%, 60$ of 150 cases; $\mathrm{p}=0.006)$ and was lower in area $\mathrm{E}(26.8 \%, 19$ of 71 cases) than in area $A(p=0.030)$ (Fig. 2). Regarding patient background, age, sex, cardiac arrest cause, place of arrest, witnesses, initial ECG, hospital ECG, shock, and adrenaline administration before arrival at a hospital did not differ significantly among the 5 areas (Table 1). The frequency of advanced airway management was significantly higher in area B than in other areas $(p=0.000)$. The time interval from emergency call to ELST arrival was significantly shorter in area $A$ than area $B(p=0.021)$ or area $C$ $(p=0.000)$, in area $D$ than in area $B(p=0.016)$ or area $C(p=0.000)$, and in area $E$ than area $C(p=0.000)$. The 


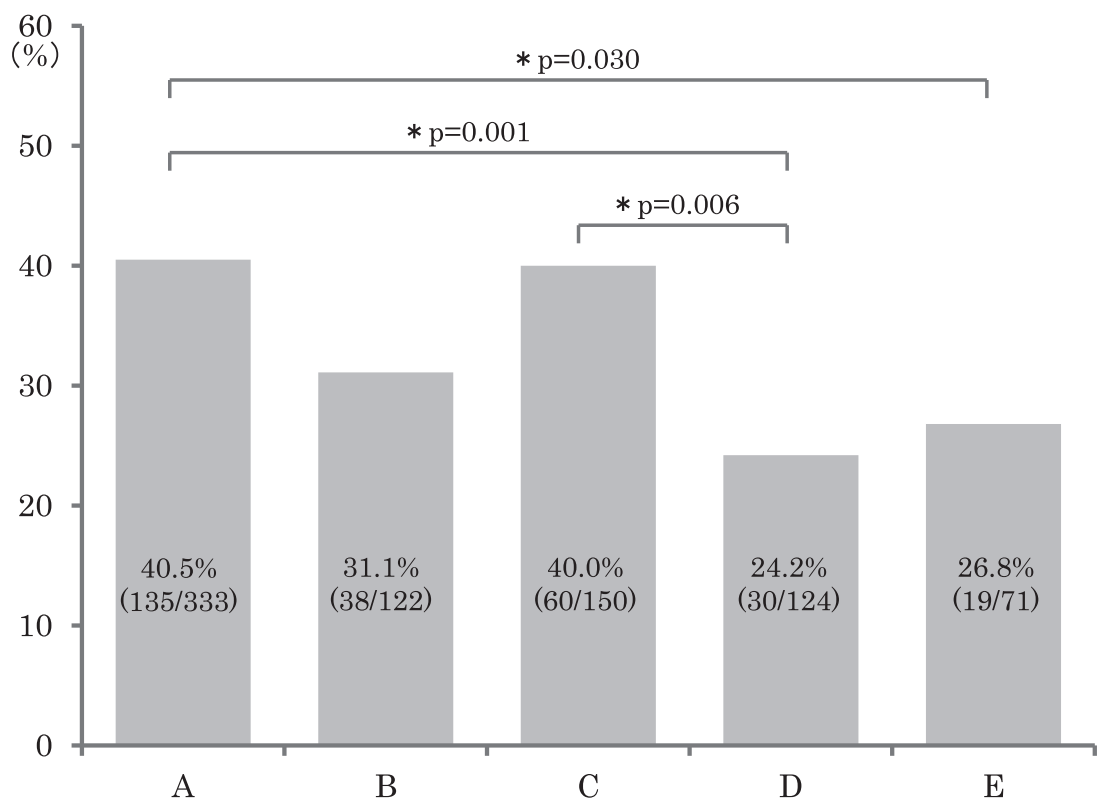

Fig. 2 Comparison of the ROSC rate in the 5 regions

time interval from ELST departure from the scene to hospital arrival was significantly shorter in area D or $\mathrm{E}$ than in area $\mathrm{A}(\mathrm{p}=0.000$ and $\mathrm{p}=0.003)$, area $\mathrm{B}$ ( $p=0.000$ and $p=0.000)$, or area $C(p=0.019$ and $p=$ 0.050) and that in area $B$ was significantly longer than that in area $\mathrm{A}(\mathrm{p}=0.000)$ or area $\mathrm{C}(\mathrm{p}=0.000)$. The ROSC rate with hospital ECG asystole was significantly higher in area $A$ than in area $B(p=$ 0.003), $D(p=0.001)$ or area $E(p=0.005)$ and was higher in area $C$ than in area $B(p=0.030)$, area $D(p=$ 0.009), or area E. There were significantly fewer examples of oral instruction given to lay person in area $\mathrm{E}$ than in area $\mathrm{A}(\mathrm{p}=0.001)$, area $\mathrm{B}(\mathrm{p}=0.003)$, area $C(p=0.001)$, or area $D(p=0.011)$ (Table 2$)$. The rate of CPR by lay person was significantly fewer in area $D$ than in area $B(p=0.011)$ or area $C(p=0.035)$, in area $\mathrm{E}$ than in area $\mathrm{B}(\mathrm{p}=0.006)$ or area $\mathrm{C}(\mathrm{p}=$ $0.018)$, and in area $A$ than in area $B(p=0.007)$ or area $\mathrm{C}(\mathrm{p}=0.026)$. CPR by lay person with a dispatcher's oral instruction did not differ significantly between the 5 areas, but almost $70 \%$ of lay person performed CPR if suitable oral instruction was given by the dispatchers. On the other hand, when no oral instructions for CPR were provided, nearly $90 \%$ of lay person did not perform CPR.

\section{Discussion}

Some valuable reports have collected countrywide data from Japan using the Utstein-style guidelines ${ }^{2-7}$. Comparison with outcomes around the world may be possible, but these studies do not reveal the advantages or problems of the resuscitation process in each region. It is necessary to compare the data from a specific region to improve the EMS in that area. The present study revealed that the ROSC rate differed significantly among the 5 regions of Saga Prefecture. The ROSC rate was significantly lower in areas $\mathrm{D}$ and $\mathrm{E}$ than in area $\mathrm{A}$ or $\mathrm{C}$. It is necessary to consider the cause of the poor ROSC rate in areas D and $\mathrm{E}$ to improve the EMS in Saga Prefecture.

There were no significant differences in many of the background factors among the 5 areas. The cause of the significant difference in areas D and E was assumed to be the low rate of CPR by lay person rather than a problem in the access time, because the access times in these areas were short. The giving of CPR instructions before EMS arrival can double the percentage of patients in cardiac arrest who receive bystander $\mathrm{CPR}$ and, in turn, can help communities achieve bystander CPR rates of more than $50 \%$ for patients in cardiac arrest who 
T. Iwamura, et al

Table 1 Comparison of the backgrounds for the 5 regions

\begin{tabular}{|c|c|c|c|c|c|c|}
\hline & $\begin{array}{l}\text { Area A } \\
(\mathrm{n}=333)\end{array}$ & $\begin{array}{l}\text { Area B } \\
(\mathrm{n}=122)\end{array}$ & $\begin{array}{l}\text { Area C } \\
(\mathrm{n}=150)\end{array}$ & $\begin{array}{l}\text { Area D } \\
(\mathrm{n}=124)\end{array}$ & $\begin{array}{l}\text { Area } E \\
(\mathrm{n}=71)\end{array}$ & $p$-value \\
\hline Mean age, years (SD) & $\begin{array}{c}72.9 \\
(18.10)\end{array}$ & $\begin{array}{c}73.5 \\
(17.57)\end{array}$ & $\begin{array}{c}75.7 \\
(17.53)\end{array}$ & $\begin{array}{c}74.2 \\
(15.34)\end{array}$ & $\begin{array}{c}73.3 \\
(18.62)\end{array}$ & 0.594 \\
\hline Male sex (n) & $\begin{array}{c}55.9 \% \\
(186)\end{array}$ & $\begin{array}{c}53.3 \% \\
(65)\end{array}$ & $\begin{array}{c}55.3 \% \\
(83)\end{array}$ & $\begin{array}{c}52.4 \% \\
(65)\end{array}$ & $\begin{array}{l}52.1 \\
(37)\end{array}$ & 0.946 \\
\hline Cardiac origin (n) & $\begin{array}{l}45.0 \% \\
(150)\end{array}$ & & $\begin{array}{c}50.0 \% \\
(75)\end{array}$ & $\begin{array}{c}46.0 \% \\
(57)\end{array}$ & $\begin{array}{c}53.5 \% \\
(38)\end{array}$ & 0.646 \\
\hline Place of cardiac arrest (n) & & & & & & 0.587 \\
\hline Home & $\begin{array}{c}62.8 \% \\
(209)\end{array}$ & $\begin{array}{c}58.2 \% \\
(71)\end{array}$ & $\begin{array}{c}62.0 \% \\
(93)\end{array}$ & $\begin{array}{c}69.4 \% \\
(86)\end{array}$ & $\begin{array}{c}63.4 \% \\
(45)\end{array}$ & \\
\hline Inside public facilities & $\begin{array}{l}2.7 \% \\
(9)\end{array}$ & $\begin{array}{c}3.3 \% \\
(4)\end{array}$ & $\begin{array}{l}4.7 \% \\
(7)\end{array}$ & $\begin{array}{l}2.4 \% \\
(3)\end{array}$ & $\begin{array}{l}4.2 \% \\
(3)\end{array}$ & \\
\hline Outside public facilities & $\begin{array}{c}17.1 \% \\
(57)\end{array}$ & $\begin{array}{c}18.0 \% \\
(22)\end{array}$ & $\begin{array}{l}16.7 \% \\
(25)\end{array}$ & $\begin{array}{c}9.7 \% \\
(12)\end{array}$ & $\begin{array}{c}22.5 \% \\
(16)\end{array}$ & \\
\hline Healthcare facilities for the elderly or clinic & $\begin{array}{c}14.1 \% \\
(47)\end{array}$ & $\begin{array}{c}14.8 \% \\
(18)\end{array}$ & $\begin{array}{c}12.0 \% \\
(18)\end{array}$ & $\begin{array}{c}16.1 \% \\
(20)\end{array}$ & $\begin{array}{l}7.0 \% \\
(5)\end{array}$ & \\
\hline Ambulance & $\begin{array}{c}3.3 \% \\
(11)\end{array}$ & $\begin{array}{l}5.7 \% \\
(7)\end{array}$ & $\begin{array}{l}4.7 \% \\
(7)\end{array}$ & $\begin{array}{l}2.4 \% \\
(3)\end{array}$ & $\begin{array}{l}2.8 \% \\
(2)\end{array}$ & \\
\hline Witnessed (n) & & & & & & 0.369 \\
\hline Witnessed by lay person & $\begin{array}{c}25.2 \% \\
(84)\end{array}$ & $\begin{array}{c}30.3 \% \\
(37)\end{array}$ & $\begin{array}{c}24.7 \% \\
(37)\end{array}$ & $\begin{array}{c}16.9 \% \\
(21)\end{array}$ & $\begin{array}{l}22.5 \% \\
(16)\end{array}$ & \\
\hline Not witnessed by lay person & $\begin{array}{l}64.3 \% \\
(214)\end{array}$ & $\begin{array}{c}61.5 \% \\
(75)\end{array}$ & $\begin{array}{c}67.3 \% \\
(101)\end{array}$ & $\begin{array}{c}72.6 \% \\
(90)\end{array}$ & $\begin{array}{l}71.8 \% \\
(51)\end{array}$ & \\
\hline Witnessed by health care workers & $\begin{array}{c}10.5 \% \\
(35)\end{array}$ & $\begin{array}{c}8.2 \% \\
(10)\end{array}$ & $\begin{array}{l}8.0 \% \\
(12)\end{array}$ & $\begin{array}{l}10.5 \% \\
(13)\end{array}$ & $\begin{array}{l}5.6 \% \\
(4)\end{array}$ & \\
\hline Initial ECG (n) & & & & & & 0.641 \\
\hline Asystole & $\begin{array}{c}70.3 \% \\
\text { (232 of 330) }\end{array}$ & $\begin{array}{c}63.9 \% \\
(78)\end{array}$ & $\begin{array}{c}68.7 \% \\
(103)\end{array}$ & $\begin{array}{c}69.9 \% \\
\text { (86 of 123) }\end{array}$ & $\begin{array}{c}77.1 \% \\
\text { (54 of } 70 \text { ) }\end{array}$ & \\
\hline Pulseless electrical activity & $\begin{array}{c}23.0 \% \\
\text { (76 of } 330)\end{array}$ & $\begin{array}{c}25.4 \% \\
(31)\end{array}$ & $\begin{array}{c}24.7 \% \\
(37)\end{array}$ & $\begin{array}{c}23.6 \% \\
\text { (29 of } 123)\end{array}$ & $\begin{array}{c}20.0 \% \\
(14 \text { of } 70)\end{array}$ & \\
\hline Ventricular fibrillation/tachycardia & $\begin{array}{c}6.7 \% \\
(22 \text { of } 330)\end{array}$ & $\begin{array}{c}10.7 \% \\
(13)\end{array}$ & $\begin{array}{l}6.7 \% \\
(10)\end{array}$ & $\begin{array}{c}6.5 \% \\
\text { (8 of 123) }\end{array}$ & $\begin{array}{c}2.9 \% \\
(2 \text { of } 70)\end{array}$ & \\
\hline Unknown (n) & 3 & 0 & 0 & 1 & 1 & \\
\hline Hospital ECG (n) & & & & & & 0.335 \\
\hline Asystole & $\begin{array}{l}76.0 \% \\
(253)\end{array}$ & $\begin{array}{c}69.7 \% \\
(85)\end{array}$ & $\begin{array}{c}74.7 \% \\
\text { (109 of 146) }\end{array}$ & $\begin{array}{c}73.4 \% \\
(91)\end{array}$ & $\begin{array}{c}69.0 \% \\
(49)\end{array}$ & \\
\hline Pulseless electrical activity & $\begin{array}{c}13.5 \% \\
(45)\end{array}$ & $\begin{array}{c}20.5 \% \\
(25)\end{array}$ & $\begin{array}{c}17.8 \% \\
(26 \text { of } 146)\end{array}$ & $\begin{array}{c}20.2 \% \\
(25)\end{array}$ & $\begin{array}{c}26.8 \% \\
(19)\end{array}$ & \\
\hline Ventricular fibrillation/tachycardia & $\begin{array}{l}2.4 \% \\
(8)\end{array}$ & $\begin{array}{l}2.5 \% \\
(3)\end{array}$ & $\begin{array}{c}2.1 \% \\
(3 \text { of } 146)\end{array}$ & $\begin{array}{l}2.4 \% \\
(3)\end{array}$ & $\begin{array}{l}0 \% \\
(0)\end{array}$ & \\
\hline Return of spontaneous circulation & $\begin{array}{l}8.1 \% \\
(27)\end{array}$ & $\begin{array}{l}7.4 \% \\
(9)\end{array}$ & $\begin{array}{c}5.5 \% \\
\text { (8 of } 146)\end{array}$ & $\begin{array}{l}4.0 \% \\
(5)\end{array}$ & $\begin{array}{l}4.2 \% \\
(3)\end{array}$ & \\
\hline Unknown (n) & 0 & 0 & 4 & 0 & 0 & \\
\hline \multicolumn{7}{|c|}{ Successful return of spontaneous circulation with hospital ECG (n) } \\
\hline Asystole & $\begin{array}{c}32.0 \% \\
\text { (81 of } 253)\end{array}$ & $\begin{array}{c}15.3 \% \\
\text { (13 of } 85)\end{array}$ & $\begin{array}{c}28.4 \% \\
\text { (31 of } 109)\end{array}$ & $\begin{array}{c}13.2 \% \\
\text { (12 of } 91)\end{array}$ & $\begin{array}{c}12.2 \% \\
(6 \text { of } 49)\end{array}$ & 0.000 \\
\hline Pulseless electrical activity & $\begin{array}{c}55.6 \% \\
\text { (25 of } 45)\end{array}$ & $\begin{array}{c}60.0 \% \\
\text { (15 of } 25)\end{array}$ & $\begin{array}{c}65.4 \% \\
(17 \text { of } 26)\end{array}$ & $\begin{array}{c}52.0 \% \\
(13 \text { of } 25)\end{array}$ & $\begin{array}{c}52.6 \% \\
(10 \text { of } 19)\end{array}$ & 0.865 \\
\hline Ventricular fibrillation/tachycardia & $\begin{array}{l}25.0 \% \\
(2 \text { of } 8)\end{array}$ & $\begin{array}{l}33.3 \% \\
(1 \text { of } 3)\end{array}$ & $\begin{array}{c}33.3 \% \\
(1 \text { of } 3)\end{array}$ & $\begin{array}{c}0 \% \\
(0 \text { of } 3)\end{array}$ & $\begin{array}{c}0 \% \\
(0 \text { of } 0)\end{array}$ & 0.740 \\
\hline \multicolumn{7}{|l|}{ Prehospital medical treatment (n) } \\
\hline Shock & $\begin{array}{c}11.1 \% \\
(37)\end{array}$ & $\begin{array}{c}13.9 \% \\
(17)\end{array}$ & $\begin{array}{c}8.0 \% \\
(12)\end{array}$ & $\begin{array}{c}10.5 \% \\
(13)\end{array}$ & $\begin{array}{l}7.0 \% \\
(5)\end{array}$ & 0.468 \\
\hline Adrenaline administration & $\begin{array}{c}3.3 \% \\
(11)\end{array}$ & $\begin{array}{c}3.3 \% \\
(4)\end{array}$ & $\begin{array}{l}2.7 \% \\
(4)\end{array}$ & $\begin{array}{l}0 \% \\
(0)\end{array}$ & $\begin{array}{l}2.8 \% \\
(2)\end{array}$ & 0.385 \\
\hline Advanced airway & $\begin{array}{l}9.0 \% \\
(30)\end{array}$ & $\begin{array}{c}34.4 \% \\
(42)\end{array}$ & $\begin{array}{l}3.3 \% \\
(5)\end{array}$ & $\begin{array}{l}8.1 \% \\
(10)\end{array}$ & $\begin{array}{l}4.2 \% \\
(3)\end{array}$ & 0.000 \\
\hline \multicolumn{7}{|l|}{ Time } \\
\hline $\begin{array}{l}\text { From emergency call to ELST arrival, min } \\
\text { (mean (SD) ) }\end{array}$ & $\begin{array}{l}8: 25 \\
(3: 19)\end{array}$ & $\begin{array}{l}\text { 9: } 38 \\
(4: 31)\end{array}$ & $\begin{array}{l}\text { 10: } 36 \\
(4: 37)\end{array}$ & $\begin{array}{l}\text { 8: } 07 \\
(2: 43)\end{array}$ & $\begin{array}{l}8: 12 \\
(3: 53)\end{array}$ & 0.000 \\
\hline $\begin{array}{l}\text { From ELST departure to hospital arrival, min } \\
\text { (mean (SD) ) }\end{array}$ & $\begin{array}{l}9: 40 \\
(5: 54)\end{array}$ & $\begin{array}{l}\text { 13: } 16 \\
(8: 16)\end{array}$ & $\begin{array}{l}9: 12 \\
(5: 50)\end{array}$ & $\begin{array}{l}6: 54 \\
(4: 38)\end{array}$ & $\begin{array}{l}6: 44 \\
(4: 54)\end{array}$ & 0.000 \\
\hline
\end{tabular}

Abbreviations: SD, standard deviation; ECG, electrocardiogram; ELST, emergency life-saving technician 
An Utstein-style Examination in Saga

Table 2 Comparison of prehospital oral instructions and CPR for the 5 regions

\begin{tabular}{|c|c|c|c|c|c|c|}
\hline & $\begin{array}{l}\text { Area A } \\
(\mathrm{n}=333)\end{array}$ & $\begin{array}{l}\text { Area B } \\
(\mathrm{n}=122)\end{array}$ & $\begin{array}{l}\text { Area C } \\
(\mathrm{n}=150)\end{array}$ & $\begin{array}{l}\text { Area D } \\
(\mathrm{n}=124)\end{array}$ & $\begin{array}{l}\text { Area } E \\
(n=71)\end{array}$ & $p$-value \\
\hline Oral instruction (n) & & & & & & 0.015 \\
\hline Oral instruction to lay person & $\begin{array}{c}64.9 \% \\
(174 \text { of } 268)\end{array}$ & $\begin{array}{c}66.0 \% \\
(70 \text { of } 106)\end{array}$ & $\begin{array}{c}66.9 \% \\
(87 \text { of } 130)\end{array}$ & $\begin{array}{c}63.3 \% \\
\text { (62 of } 98)\end{array}$ & $\begin{array}{c}42.1 \% \\
(24 \text { of } 57)\end{array}$ & \\
\hline $\begin{array}{l}\text { No oral instruction to lay } \\
\text { person }\end{array}$ & $\begin{array}{c}35.1 \% \\
\text { (94 of } 268)\end{array}$ & $\begin{array}{c}44.0 \% \\
(36 \text { of } 106)\end{array}$ & $\begin{array}{c}33.1 \% \\
(43 \text { of } 130)\end{array}$ & $\begin{array}{c}36.7 \% \\
\text { (36 of } 98)\end{array}$ & $\begin{array}{c}57.9 \% \\
(33 \text { of } 57)\end{array}$ & \\
\hline $\begin{array}{l}\text { Oral instruction not needed: } \\
\text { CPR by healthcare workers (n) }\end{array}$ & 42 & 14 & 16 & 19 & 5 & \\
\hline Unknown (n) & 23 & 2 & 4 & 7 & 9 & \\
\hline Prehospital CPR (n) & & & & & & 0.005 \\
\hline CPR by lay person & $\begin{array}{c}44.0 \% \\
\text { (128 of } 291)\end{array}$ & $\begin{array}{c}59.3 \% \\
(64 \text { of } 108)\end{array}$ & $\begin{array}{c}55.6 \% \\
\text { (74 of } 133)\end{array}$ & $\begin{array}{c}41.9 \% \\
(44 \text { of } 105)\end{array}$ & $\begin{array}{c}37.9 \% \\
(25 \text { of } 66)\end{array}$ & \\
\hline No CPR by lay person & $\begin{array}{c}56.0 \% \\
\text { (163 of } 291)\end{array}$ & $\begin{array}{c}40.7 \% \\
\text { (44 of } 108)\end{array}$ & $\begin{array}{c}44.4 \% \\
\text { (59 of } 133)\end{array}$ & $\begin{array}{c}58.1 \% \\
\text { (61 of } 105)\end{array}$ & $\begin{array}{l}62.1 \% \\
(41 \text { of } 66)\end{array}$ & \\
\hline CPR by healthcare workers (n) & 42 & 14 & 16 & 19 & 5 & \\
\hline Unknown (n) & 0 & 0 & 1 & 0 & 0 & \\
\hline $\begin{array}{l}\text { CPR by lay person with oral } \\
\text { instruction (n) }\end{array}$ & $\begin{array}{c}66.7 \% \\
\text { (116 of } 174)\end{array}$ & $\begin{array}{c}80.0 \% \\
(56 \text { of } 70)\end{array}$ & $\begin{array}{c}78.2 \% \\
\text { (68 of } 87)\end{array}$ & $\begin{array}{c}69.4 \% \\
(43 \text { of } 62)\end{array}$ & $\begin{array}{c}79.2 \% \\
\text { (19 of } 24)\end{array}$ & 0.127 \\
\hline $\begin{array}{l}\text { No CPR by lay person without } \\
\text { oral instruction (n) }\end{array}$ & $\begin{array}{c}90.4 \% \\
(85 \text { of } 94)\end{array}$ & $\begin{array}{c}80.6 \% \\
(29 \text { of } 36)\end{array}$ & $\begin{array}{c}88.4 \% \\
(38 \text { of } 43)\end{array}$ & $\begin{array}{c}97.2 \% \\
(35 \text { of } 36)\end{array}$ & $\begin{array}{l}84.8 \% \\
(28 \text { of } 33)\end{array}$ & 0.213 \\
\hline
\end{tabular}

Abbreviation: CPR, cardiopulmonary resuscitation

collapse before ELST arrival ${ }^{10}$. The 2010 American Heart Association guidelines recommended that all dispatchers be appropriately trained to provide $\mathrm{CPR}$ instructions by telephone (Class I, level of evidence $B)^{11-19}$. In addition, the EMS quality-improvement process, including review of the quality of dispatcher CPR instructions provided to specific callers, is considered an important component of a high-quality lifesaving program (Class IIa, level of evidence $\mathrm{B})^{11,20-22}$. Of course, dispatcher-assisted CPR is regularly performed in Saga Prefecture. However, when someone makes an emergency call for the first time, such callers tend to be upset and in a state of panic, and, therefore, in some cases cardiopulmonary arrest develops after the first call because the caller could not sufficiently verify a disturbance of consciousness or respiratory arrest. For such cases in which cardiopulmonary arrest cannot be ruled out, reconfirmation by the emergency team on its way to the scene should be considered. We believe that if the original caller is called back from the ambulance with the sound of the siren in the background and is told that an emergency team is on its way, the caller will feel relieved and be able to respond more calmly. However, at present, not all emergency teams in Saga prefecture perform this reconfirmation. On the basis of the above factors, we speculate that verifying the quality of oral instructions is necessary in area D, although it had an average rate, and that the strategies to increase the rate of oral instruction itself should be reconsidered in area $\mathrm{E}$ in addition to verifying the quality of such instructions. Regarding specific strategies, we believe that dispatchers should be retrained and revisions of oral instruction manual should be conducted, such as by including this reconfirmation from the ambulance that is en route.

Almost $70 \%$ of lay person was able to perform CPR if suitable oral instructions were provided. On the other hand, no CPR was performed in $90 \%$ of cases without suitable oral instructions. Interviews with each fire department showed that the rate of the general public attending resuscitation training in area $\mathrm{E}$ over the past 3 years was $13.2 \%$, which was higher than in the other 4 areas (area A: $8.6 \%$; area B: 12.7\%; area C: 8.9\%; and area D: 6.0\%) (personal communication, $\mathrm{K}$ Yoshida, November 2011). Therefore, taking this point into consideration, resuscitation training alone does not give members of the general public the confidence to act appropriately in an emergency; therefore, we believe that it is extremely important for the control center or emergency team to encourage bystanders to perform CPR while the ambulance is en route (e.g.: 
"An ambulance is on its way. The injured or sick individual needs CPR. Please perform CPR. I will tell you how to do it."). Previous reports also describe that when the rate of bystander CPR is low, which, therefore, contributes to a low survival rate in many areas and despite large-scale training efforts, the rate of bystander CPR has historically remained at a low level, and this encouragement is believed be an important factor for increasing the rate of bystander $\mathrm{CPR}^{11}$

The ROSC rate with hospital ECG asystole was significantly higher in areas $\mathrm{A}$ and $\mathrm{C}$. This result might have contributed to increasing the overall ROSC rate. Appropriate implementation of ACLS, including the continuation of the "chain of survival" from before arrival at the hospital, occurred in these 2 areas. Conversely, the need to strengthen the ACLS is suggested in areas B, D, and E. In addition, the ROSC rate remained in the middle range in area $\mathrm{B}$, despite advanced airway management being frequently performed by ELSTs. In fact, prehospital advanced airway management reportedly does not contribute to either the survival rate or the discharge rate ${ }^{23-25}$. However, an evaluation of the efficacy limited to the respiratory origin is necessary in the future.

The evaluation of bystander CPR includes situations in which a dispatcher's providing oral instructions is difficult at the time of the first emergency call, such as during a rescue from neardrowning or hanging. However, determining whether the dispatcher should provide oral instructions to such bystanders is extremely difficult. Therefore, aggregate was performed in a form that includes near-drowning, hanging, traffic accidents, and calls by third parties, possibly resulting in a false decrease in the performance of bystander CPR. In addition, we are concerned about some problems that are considered unique to Japan. The incidence of treated OHCA ranges from 50 to 60 per 100,000 person-years and is comparable to that in many parts of the world ${ }^{11}$. The incidence of treated OHCA in this study was estimated to be $94.1 / 100,000$ people in Saga Prefecture and was higher than the average incidence worldwide. The problem of Japan's aging population may affect these results. An aging society introduces other factors, such as many bystanders being elderly and, thus, unable to perform $\mathrm{CPR}^{6}$.

Favorable neurological outcomes were not evaluated in this study because the submitted data often lacked final outcomes and because the number of cases with good outcomes per region was insufficient. However, 1-month survival rates and long-term outcomes should be evaluated in future studies.

The main purpose of the present study was to help improve regional EMSs. As described above, clearly identifying the advantages and problems of the resuscitation process and disseminating this information were extremely difficult because various factors influence the entire process. However, we believe it is extremely important to try to increase the ROSC rate of each region by addressing each related factor and by disseminating this information to verify and effectively use the Utstein-style criteria in each region.

\section{Conclusions}

This detailed study of the Utstein-style guidelines has clarified differences in the ROSC rate in Saga Prefecture and provided information that will help improve regional EMSs. Training of the general public in BLS and of medical personnel in ACLS, improvements in the quality of oral instructions, and appropriate revisions of the oral instruction manual are expected to improve ROSC rates in the applicable areas. It is important to reaffirm the effectiveness of CPR and encourage lay person to perform CPR by providing instructions by telephone from an ambulance en route to the scene. To improve regional EMSs, it is required not only a national comparative study but also detailed studies from various regions of Japan.

\section{References}

1. Cummins RO, Chamberlain DA, Abramson NS, et al:: Recommended guidelines for uniform reporting of data from out-of-hospital cardiac arrest: the Utstein Style. A statement for health professionals from a task force of the American Heart Association, the European Resuscitation Council, the Heart and Stroke Foundation of Canada, and the Australian 
Resuscitation Council. Circulation 1991; 84: 960-975.

2. Kitamura T, Iwami $T$, Kawamura $T$, et al.: Conventional and chest-compression-only cardiopulmonary resuscitation by bystanders for children who have out-of-hospital cardiac arrests: a prospective, nationwide, population-based cohort study. Lancet 2010; 375: 1347-1354.

3. Kitamura T, Iwami T, Kawamura T, Nagao K, Tanaka H, Hiraide A: Nationwide public-access defibrillation in Japan. N Engl J Med 2010; 362: 9941004.

4. Kitamura T, Iwami T, Kawamura T, et al.: Timedependent effectiveness of chest compression-only and conventional cardiopulmonary resuscitation for out-of-hospital cardiac arrest of cardiac origin. Resuscitation 2011; 82: 3-9.

5. Koike S, Ogawa T, Tanabe S, et al.: Collapse-toemergency medical service cardiopulmonary resuscitation interval and outcomes of out-of-hospital cardiopulmonary arrest: a nationwide observational study. Crit Care 2011; 15: R120.

6. Yasunaga $\mathrm{H}$, Miyata $\mathrm{H}$, Horiguchi $\mathrm{H}$, et al: Population density, call-response interval, and survival of out-of-hospital cardiac arrest. Int J Health Geogr 2011; 10: 26.

7. Abe T, Nagata T, Hasegawa M, Hagihara A: Life support techniques related to survival after out-ofhospital cardiac arrest in infants. Resuscitation 2012; 83: 612-618.

8. Saga Prefecture statistical yearbook ver 2010. Chapter 1. Available at http://www.pref.saga.lg.jp/ web/kensei/_1366/toukei/t-sougou/t-nenpou/_56236. html\#3. Accessed 16 April 2012.

9. Emergency Life-Saving Technician's Law. Ministry of Health, Labour and Welfare. Available at http:// wwwhourei.mhlw.go.jp/cgi-bin/t_docframe2.cgi? $\mathrm{MODE}=$ hourei\&DMODE $=\mathrm{SEARCH} \& \mathrm{SMODE}=$ NORMAL\&KEYWORD $=\% 8 \mathrm{~b} \% 7 \mathrm{e} \% 8 \mathrm{~b} \% 7 \mathrm{~d} \% 8 \mathrm{~b} \% 7 \mathrm{e} \%$ $96 \%$ bd $\% 8 \mathrm{e} \% 6 \mathrm{~d} \& \mathrm{EFSNO}=226 \& \mathrm{FILE}=\mathrm{FIRST} \& \mathrm{POS}=0$ \&HITSU $=63$. Accessed 16 April 2012.

10. Rea TD, Eisenberg MS, Becker LJ, Murray JA, Hearne T: Temporal trends in sudden cardiac arrest: a 25-year emergency medical services perspective. Circulation 2003; 107: 2780-2785.

11. Lerner EB, Rea TD, Bobrow BJ, et al: Emergency Medical Service Dispatch Cardiopulmonary Resuscitation Prearrival Instructions to Improve Survival From Out-of-Hospital Cardiac Arrest: A Scientific Statement From the American Heart Association. Circulation 2012; 125: 648-655.

12. Berg RA, Hemphill R, Abella BS, et al.: Part 5: adult basic life support: 2010 American Heart Association Guidelines for Cardiopulmonary Resuscitation and Emergency Cardiovascular Care. Circulation 2010; 122: S685-S705.

13. Calle PA, Lagaert L, Vanhaute O, Buylaert WA: Do victims of an out-of-hospital cardiac arrest benefit from a training program for emergency medical dispatchers? Resuscitation 1997; 35: 213-218.

14. Emergency medical dispatching: rapid identification and treatment of acute myocardial infarction: National Heart Attack Alert Program Coordinating Committee Access to Care Subcommittee. Am J Emerg Med 1995; 13: 67-73.

15. Hallstrom A, Cobb L, Johnson E, Copass M: Cardiopulmonary resuscitation by chest compression alone or with mouth-to-mouth ventilation. N Engl J Med 2000; 342: 1546-1553.

16. Culley LL, Clark JJ, Eisenberg MS, Larsen MP: Dispatcher-assisted telephone CPR: common delays and time standards for delivery. Ann Emerg Med 1991; 20: 362-366.

17. Berdowski J, Beekhuis F, Zwinderman AH, Tijssen JG, Koster RW: Importance of the first link: description and recognition of an out-ofhospital cardiac arrest in an emergency call. Circulation 2009; 119: 2096-2102.

18. Kuisma M, Boyd J, Väyrynen T, Repo J, Nousila-Wiik M, Holmström P: Emergency call processing and survival from out-of-hospital ventricular fibrillation. Resuscitation 2005; 67: 89-93.

19. Rea TD, Eisenberg MS, Culley LL, Becker L: Dispatcher-assisted cardiopulmonary resuscitation and survival in cardiac arrest. Circulation 2001; 104: 2513-2516.

20. Heward A, Damiani M, Hartley-Sharpe C: Does the use of the Advanced Medical Priority Dispatch System affect cardiac arrest detection? Emerg Med J 2004; 21: 115-118.

21. Roppolo LP, Westfall A, Pepe PE, et al: Dispatcher assessments for agonal breathing improve detection of cardiac arrest. Resuscitation 2009; 80: 769-772.

22. Bohm K, Stålhandske B, Rosenqvist M, Ulfvarson J, Hollenberg J, Svensson L: Tuition of emergency medical dispatchers in the recognition of agonal respiration increases the use of telephone assisted CPR. Resuscitation 2009; 80: 1025-1028.

23. Shin SD, Ahn KO, Song KJ, Park CB, Lee EJ: Out-ofhospital airway management and cardiac arrest outcomes: a propensity score matched analysis. Resuscitation 2012; 83: 313-319.

24. Hanif MA, Kaji AH, Niemann JT: Advanced airway management does not improve outcome of out-ofhospital cardiac arrest. Acad Emerg Med 2010; 17: 926-931.

25. Lyon RM, Ferris JD, Young DM, McKeown DW, Oglesby AJ, Robertson C: Field intubation of cardiac arrest patients: a dying art? Emerg Med J 2010; 27 : 321-323.

(Received, July 2, 2012)

(Accepted, November 27, 2012) 